\title{
"Os bens e o sangue": uma leitura do tema da família na poesia de Drummond
}

\section{Alexandre Nell Schmidtke}

\begin{abstract}
Resumo: Este trabalho apresenta algumas reflexões acerca da temática da família na obra de Carlos Drummond de Andrade. Partindo do poema "Os bens e o sangue", do livro Claro Enigma, nós podemos reinterpretar a obra que o precede e encontrar uma possível origem para esta inquietude. Neste poema, a família de Drummond (ou pelo menos a família do eu poético) ganha voz e deserda os descendentes de todos os bens materiais. Isso situa historicamente diversos conflitos como, por exemplo, a gaucherie e a relação com sua cidade natal, já que se trata de um descendente de fazendeiros que abandona o universo rural e parte para a grande cidade. A relação tensa com a tradição familiar é uma constante na obra do poeta mineiro desde Alguma Poesia e constitui uma espécie de círculo poético, que tem seu fechamento em Claro Enigma.
\end{abstract}

Palavras-chave: Carlos Drummond de Andrade; Poesia brasileira; Patriarcalismo.

\begin{abstract}
This article presents some reflections on the family matter in the works of Carlos Drummond de Andrade. Starting from the poem "Os bens e o sangue", from the book Claro Enigma, we can reinterpret the previous works and find out a possible origin for that disquietness. In this poem, Drummond's family (or at least the lyric poet's family) makes its voice heard and disinherits the descendants from all its possessions. It places historically many coflicts such as the gaucherie and the relationship with his home town, since he is descended from farmers but leaves the rural universe and goes to the big city. The tense relationship with the family tradition is constant in the Mineiro poet's works since Alguma Poesia and also constitutes a kind of poetic circle, which has closing end in Claro Enigma.
\end{abstract}

Keywords: Carlos Drummond de Andrade; Brazilian Poetry; Patriarchy.

O senhor tem saudades de Itabira ainda hoje?

Tenho uma profunda saudade e digo mesmo: no fundo, continuo morando em Itabira, através das minhas raízes e, sobretudo, através dos meus pais e dos meus irmãos, todos nascidos lá e todos já falecidos. É uma herança atávica profunda que não posso esquecer. (Entrevista de Drummond a Geneton Moraes Neto, em Dossiê Drummond, p.62.)

\section{1 "Poema de sete faces"}

A obra poética de Drummond é permeada pela lembrança de seus familiares. Há pelo menos dois momentos poéticos distintos em que essa lembrança se revela: nos livros de 1930 a 1951, respectivamente, de Alguma Poesia a Claro Enigma, que se caracterizam pela inquietude, pela tensão poética; e na série Boitempo, que pode ser lida como literatura

\footnotetext{
* Mestrando em Literatura Brasileira no PPGLET da UFRGS.
} 
memorialística ${ }^{1}$, onde a tensão é diminuída tanto na força do sentimento quanto na matéria estética.

A fim de analisarmos como o tema da família acompanha e determina outras temáticas de Drummond nesse período, tomamos como referência um poema que julgamos essencial para sua compreensão: “Os bens e o sangue" (p.282)2. Trata-se de um poema no qual a família anuncia sua herança ao poeta e que define, entre outras coisas, a própria temática da família. Segundo Candido (2004, p.85), "é o poema que estabelece a ligação entre o passado da família e o presente do indivíduo, através da forma altamente significativa de um testamento". Além disso, ao definir a gaucherie, herdada, do sujeito lírico, esse poema nos proporciona encontrar uma possível raiz deste traço tão importante na obra de Drummond.

Temos, então, uma situação determinante para a poética drummondiana, já que, se assim for, características importantes como a busca do diálogo com o pai, "a idéia da família viajando através da carne", a relação com sua cidade natal, e, talvez mais importante ainda, a própria gaucherie deverão ser determinadas por uma herança familiar. Interessa, pois, estudar como essa herança é expressa em Alguma Poesia, Sentimento do Mundo, José, Rosa do Povo e Claro Enigma ${ }^{3}$. Com essa finalidade, serão analisados aqui os seguintes poemas: "Poema de sete faces" (p.5), "Infância” (p.6), "Confidência do Itabirano" (p.68), "Viagem na família" (p.110), e "Os bens e o sangue" (p.282)

O fato de o primeiro poema do primeiro livro de poesias de Carlos Drummond de Andrade iniciar com uma estrofe na qual ele se declara gauche é significativo, pois é essa tortuosidade que caracteriza o eu lírico pelo menos nas obras aqui estudadas. No "Poema de sete faces", um "anjo torto" predestina o poeta em seu nascimento a ser um gauche na vida. Mesmo tendo uma aparente redução da problematização dos temas abordados mediante a experimentação estética, "Poema de sete faces" (p.5) se revela decisivo também pelo problema levantado. Cabe a leitura do poema:

\footnotetext{
${ }^{1}$ Segundo Candido, na série autobiográfica Boitempo o "intuito autobiográfico não ocorre sob o aspecto de autoanálise, dúvida, inquietude, sentimento de culpa, ou seja, as vestimentas com que aparece na maioria da lírica de Drummond; mas com aquele sentimento do mundo como espetáculo, que se configura nalguns poemas de Lição de Coisas". (CANDIDO, Antonio. "Poesia e ficção na autobiografia". In: A educação pela noite. Rio de Janeiro: Ouro sobre Azul, 2006, p.66)

${ }^{2}$ Todos os poemas aqui mencionados estão em ANDRADE, Carlos Drummond de. Poesia Completa. Rio de Janeiro: Editora Nova Aguilar S.A., 2003, de modo que citaremos apenas o número da página.

${ }^{3}$ É curioso que Brejo das Almas, o segundo volume de poesias de Drummond, não apresenta nenhuma poesia sobre a temática da família. Para possíveis razões, ver CAMILO, Vagner. Uma poética da indecisão: Brejo das Almas. In: Novos estudos CEBRAP, São Paulo, № 57, pp. 37-58, julho 2000.

${ }^{4}$ Poderiam ser analisados ainda diversos outros poemas, como "Família" (p.26), "Sesta" (p.33), "Edifício Esplendor" (p.96), "Retrato de família" (p.182), "Como um presente" (p.186), "Rua da Madrugada" (p.188), "No país dos Andrades" (p.194), "Convívio" (p.287), "Permanência" (p.288), "Perguntas" (p.288), "Carta", (p.290), "Encontro" (p.290), “A mesa" (p.292).
} 


\section{Poema de sete faces}

Quando nasci, um anjo torto desses que vivem na sombra disse: Vai, Carlos! ser gauche na vida.

As casas espiam os homens que correm atrás de mulheres. A tarde talvez fosse azul, não houvesse tantos desejos.

O bonde passa cheio de pernas: pernas brancas pretas amarelas.

Para que tanta perna, meu Deus, pergunta meu coração.

Porém meus olhos

não perguntam nada.

O homem atrás do bigode

é sério, simples e forte.

Quase não conversa.

Tem poucos, raros amigos

o homem atrás dos óculos e do bigode,

Meu Deus, por que me abandonaste

se sabias que eu não era Deus

se sabias que eu era fraco.

Mundo mundo vasto mundo, se eu me chamasse Raimundo seria uma rima, não seria uma solução.

Mundo mundo vasto mundo, mais vasto é meu coração.

Eu não devia te dizer

mas essa lua

mas esse conhaque

botam a gente comovido como o diabo.

$\mathrm{Na}$ leitura que propomos aqui, o anjo torto relaciona-se com o que é deixado de herança ao poeta por seus ancestrais ainda que, neste primeiro momento, a gaucherie seja vista como vinda do sobrenatural, a anunciação do anjo. Além disso, a religião é vista como paródia, para a qual o eu lírico apela num momento em que ainda não encontra uma explicação para sua tortuosidade. Além de caracterizar psicologicamente o sujeito lírico, a gaucherie encerra também uma idéia de fatalidade, que acarreta inevitavelmente uma condição de derrota. Temos, assim, um gauche que não faz necessariamente uma poesia derramada; um sujeito lírico destinado à derrota sem, no entanto, assumir uma condição inferiorizada; e um poeta que canta a família, que por sua vez é definidora de sua personalidade.

Como diz Candido (2004: p.70), "na obra de Drummond, essa torção é um tema, menos no sentido tradicional de assunto, do que no sentido específico da moderna psicologia 
literária: um núcleo emocional a cuja volta se organiza a experiência poética". Assim, o modo como o autor poetiza sua família - já que ela representa este núcleo emocional - e o fato de ser o sujeito lírico esse "eu todo retorcido" estão diretamente relacionados com a predestinação feita por seus ancestrais. Ou seja, é inevitável que a poesia familiar de Drummond seja feita através dessa inquietude, desse olhar retorcido.

De qualquer maneira, é importante reconhecermos as diversas manifestações da gaucherie que não estudaremos aqui ${ }^{5}$. De fato, o olhar sob a perspectiva da tortuosidade constitui também parte da poesia de cunho social de Drummond, mas o que nos interessa é como o gauche fala da família, pois parece haver aí uma relação indissociável.

Sant'anna diz que o gauche representa aquele que é expulso de sua terra, "que deixa seu clã familiar, larga a estabilidade do mundo provinciano e se lança em direção ao mar, para viver perigosamente num edifício sobre areias”. (SANT'ANNA, 1972, p.34).

Esse afastamento da família nos mostra outro aspecto da gaucherie (sendo também um traço que a define), pois conforme vaticinavam os ancestrais em "Os bens e o sangue", o poeta deveria primeiro negar a família para depois cantá-la. Assim, em Alguma Poesia, o anjo que anuncia "vai, Carlos! ser gauche na vida" representaria também a voz familiar "expulsando" o poeta de sua família, que vende seus bens não lhe deixando nada material como herança. Talvez o verbo "expulsar", neste caso, seja forte demais porque o poeta não abandona a família por completo. No entanto, é nesse momento que ocorre a anunciação da negação da família, tarefa do poeta. Podemos, então, compreender essa ordem do anjo torto como o momento em que o poeta se retira da família. Se assim for, esse momento é o nascimento do poeta, o que o torna um gauche já predestinado.

A composição do poema nos apresenta um movimento de oscilação entre peso e leveza, importante para sua compreensão. A primeira e quinta estrofes expressam o peso, a matéria poética mais densa, ao passo que as demais amenizam essa densidade. Mesmo que o poeta esteja "empenhado num esforço conceitual de dizer com precisão o que vai no coração, buscando reconhecer os próprios sentimentos" (ARRIGUCCI, 2002: p. 41) em todas as estrofes do poema, a anunciação do destino pelo anjo torto e o reconhecimento da fraqueza na interpelação a Deus são significativos quando nos damos conta de que o anjo torto pode estar representando a voz da família, conforme já vimos, e que a referência ao momento da crucificação é também o reconhecimento da fraqueza do poeta perante o pai. Ou seja, o poeta estabelece as relações Cristo/eu lírico e Deus/pai e indaga este último quanto ao fato de tê-lo

\footnotetext{
${ }^{5}$ Sant' anna traça uma série de considerações sobre a caracterização do gauche (cf. SANT'ANNA, 1972, p.43).
} 
abandonado, apesar do reconhecimento de sua fraqueza. Trata-se de um dos principais temas, ou inquietudes, de Drummond expressa de forma irônica, porém com significativa tensão.

Arrigucci nota o movimento fundamental nesse momento poético de Drummond:

Desde esse princípio, Drummond parece empenhado num esforço conceitual de dizer o que vai no coração, buscando reconhecer os próprios sentimentos. E desde o começo o desafio do difícil está lançado, pois o poeta encontra no coração o caminho da dificuldade: um destino verdadeiramente stendhaliano (...). É que persegue com palavras precisas até os movimentos imperceptíveis do coração, arriscando-se a procurar pela reflexão o que não se pode dizer, aquilo a que falta nome. (ARRIGUCCI, 2002: p. 41)

Se o "Poema de sete faces" é a reflexão do poeta sobre seu sentimento de estar no mundo" (Arrigucci, 2002), fica claro que o poeta busca uma expressão também para os conflitos familiares. Porém, como vimos, isso está no plano do que "não se pode dizer", do que "falta nome". Dessa forma, o anjo torto e a referência à crucificação ultrapassam a paródia, chocante para os padrões da época, e tentam expressar o que ainda é indizível. Daí a apelação para o sobrenatural, para a paródia religiosa, algo aparentemente distante da realidade do poeta, mas que já contém o drama poético de Drummond.

\section{Infância}

Também de Alguma Poesia, "Infância" (p.6) apresenta um momento significativo para o assunto aqui abordado. Nele podemos notar traços dessa gaucherie através de uma espécie de quadro familiar. Temos uma situação em que o distanciamento do poeta ainda criança revela uma característica chave de sua obra. É certo que o olhar do sujeito lírico não infantiliza a poesia, pelo contrário, apresenta um conflito intenso sob a aparente estagnação do quadro.

Segundo Antonio Candido (2004), há na obra de Carlos Drummond de Andrade um movimento quanto à matéria poética sobre a qual trabalha o poeta. Esse movimento, que se dá entre 1930 e 1959, ou seja, entre Alguma Poesia e Lição de Coisas é a passagem do "reconhecimento do fato", ou poesia registro, para uma "desconfiança aguda sobre o que (o poeta) diz e faz", ou 'poesia processo' (de Brejo das Almas para Sentimento do Mundo) e, por fim, o retorno ao momento inicial, porém com um "requinte maior com a palavra" em Lição de Coisas ${ }^{6}$. Então, se em seu primeiro livro Drummond parte do "reconhecimento do fato", podemos pensar "Infância" como sendo um poema em que o grau de problematização é

\footnotetext{
${ }^{6}$ CANDIDO, Antonio. "Inquietudes na poesia de Drummond". In: Vários escritos. Rio de Janeiro: Ouro sobre Azul; São Paulo: Livraria Duas Cidades, 2004. p. 67.
} 
reduzido em detrimento da apresentação da situação. Veremos, não obstante, que essa apresentação revela conflitos que nesse momento ainda não vieram à tona, que encontrarão uma expressão poética mais tensa posteriormente.

A fim de notarmos como isso acontece, ressaltamos os seguintes aspectos: o ato da leitura afasta o menino da família; a relação menino/Robinson Crusoé, na qual a história daquele é mais bonita do que a deste; e a relação Robinson Crusoé/eu lírico, cujo olhar, já distanciado da infância, determina o lugar de onde fala.

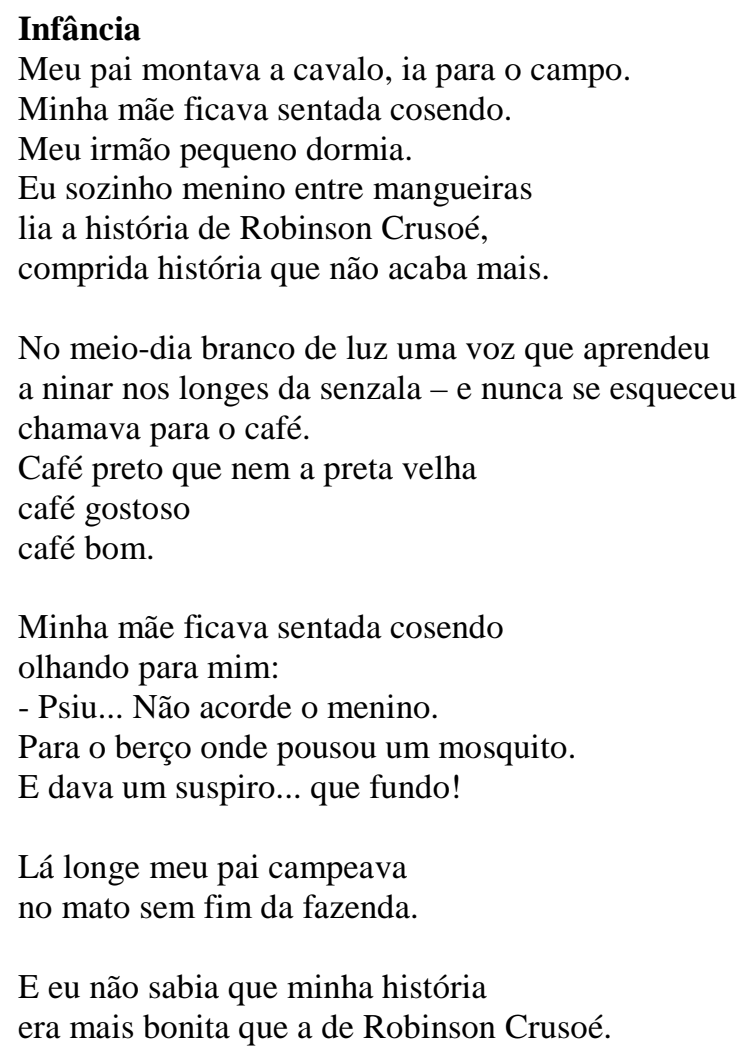

A primeira estrofe já nos apresenta o todo da situação: os membros da família (pai, mãe, irmão) ocupados em suas rotinas (claramente ligadas ao universo do campo) e o menino lendo a história de Robinson Crusoé. Além desses personagens, há também a "preta velha", figura relevante no poema.

O menino está afastado dos demais membros da família. É um afastamento, todavia, principalmente no plano do pensamento, já que fisicamente todos os membros da família estão afastados, o que reduz a tensão nesse sentido: o pai no campo, a mãe cosendo, o irmão dormindo e o menino entre as mangueiras. Entretanto, se todos os membros da família estão afastados, a "voz que aprendeu a ninar nos longes da senzala", a "preta velha", ao contrário, agrega a família. Ela é o foco da segunda estrofe, contrastando nitidamente com a separação 
física dos demais personagens. Esse contraste será ainda intensificado nas duas estrofes seguintes, cujo foco é a mãe cuidando do menino dormindo e o pai campeando na fazenda.

Temos então um movimento de distanciamento e aproximação, movimento que tem dois planos nítidos: o físico e o do pensamento. No plano físico, a família está afastada (exceto a mãe e o irmão pequeno, bebê pelo que nos indica o berço). $\mathrm{O}$ distanciamento é dado pelo pai, que "montava a cavalo, ia para o campo" e pela mãe, que "ficava sentada cosendo". Essas imagens são repetidas nas estrofes 3 e 4, respectivamente: "Minha mãe ficava sentada cosendo", o mesmo verso da primeira estrofe, e "Lá longe meu pai campeava". A aproximação física é dada pela "preta velha", pela sua voz.

No plano do pensamento, ao contrário, a família encontra-se unida nas lides da fazenda: o pai campeando; a mãe cosendo ou cuidando do irmão pequeno, que dorme; a "preta velha" na cozinha.

O movimento de afastamento no plano do pensamento é dado pelo poeta ainda menino lendo a história de Robinson Crusoé. É necessário compreender em que medida essa história contribui para o poema. Um dado significativo é que Robinson Crusoé, a fim de se lançar nas suas aventuras, precisou romper e desobedecer às palavras do pai. No entanto, em muitos momentos (principalmente nas grandes dificuldades), o sentimento de culpa prevalece, e o aventureiro inglês lembra-se dos conselhos paternos, agora sábios. Watt nos diz, a respeito das inusitadas infelicidades de Crusoé, que "isso poderia sugerir que o [mito] de Crusoé é essencialmente punitivo. Crusoé é punido por sua tendência ao nomadismo, seu desejo de uma vida mais aventurosa do que aquela que teria se houvesse obedecido ao pai e permanecido em casa". (WATT, 1997, p.170). Mesmo Ian Watt ressaltando que esta é uma característica do herói muitas vezes bastante amenizada e ainda "contra a moral operativa do livro", é um traço importante da narrativa, pois é principalmente a resistência do pai que representa a voz contrária à viagem do aventureiro. Assim, Crusoé deve romper com o pai e com sua tradição familiar de vida calma e confortável a fim de se lançar ao mar. Watt (1997, p.172) diz ainda que no romance de Defoe há o "apelo universal da solidão". Essa não parece ser uma solidão exatamente maléfica para Crusoé, já que ele a compensa de diversas outras maneiras ${ }^{7}$. Todavia, quando pensamos no eu lírico do poema de Drummond (e quando ampliamos a leitura para a figura do gauche), essa parece ser uma marca negativa, já que a

\footnotetext{
7 Para uma abordagem mais completa do assunto, cf. "Robinson Crusoe". In: WATT, Ian. Mitos do Individualismo moderno: Fausto, Dom Quixote, Dom Juan, Robinson Crusoe. Rio de Janeiro: Jorge Zahar, 1997.
} 
infância era bela. Talvez a história do menino fosse mais bonita porque ainda não havia rompido com o pai.

Há vários elementos no poema que representam tranqüilidade: a mãe cosendo, o irmão dormindo, o menino sozinho lendo, o café gostoso. Mais do que isso, o ritmo do poema, marcado pelos versos pausados, imprime a calma da vida rural. Diante desse ritmo, logo vem à tona a imagem da família mineira de "Sesta", em que "só um mosquito rápido / mostra inquietação" (p. 33) ou de "Cidadezinha qualquer" (p. 23), em que a cidade pode ser compreendida como a extensão do campo. Em "Infância" parece não haver inquietação nem por parte do mosquito. A tensão do poema é dada pelo eu lírico já distanciado da infância.

No que diz respeito à história de Crusoé no poema, há também um momento de aproximação e outro de distanciamento: aproximação quando o menino, sozinho entre mangueiras, lê a história, e ainda está incluso no núcleo familiar no plano físico. Diante desse mundo pacato da família mineira, o jovem leitor se aproxima do livro para se distanciar da pasmaceira, da ausência de movimento; e distanciamento quando mencionada a história de Crusoé na última estrofe, em que o eu lírico olha para a infância e a vê como sendo esta mais bonita do que aquela, o que é feito através do verbo no pretérito imperfeito. Ou seja, a questão a ser colocada é que se a história era mais bonita, agora já não é mais. Essa é a marca do eu poético já adulto, que se coloca em situação semelhante à de Robinson Crusoé. E se pensarmos que essa pode ser a história de um homem que rompe com a família (principalmente com figura paterna) e vive só, o eu lírico se revela um gauche.

Temos, portanto, em "Infância" o sujeito lírico distante da família reconhecendo um momento agradável em sua integração, pois é na infância que sua história é mais bonita que a de Robinson Crusoé. Voltando ao que disse Antonio Candido, parece claro que a poesia familiar de Drummond ainda não é tensionada como virá a ser a partir de Sentimento do Mundo. Mas sob essa imagem da família sem movimento, aparentemente sem tensão, notamos o olhar do gauche, conforme vimos a respeito de "Poema de sete faces".

Além disso, parece haver aí uma espécie de recalque, pois a imagem que fica da família e de Itabira é de algo estagnado (tanto que o menino precisa do livro para fugir desse ambiente), como a vida besta de "Cidadezinha qualquer". Em Sentimento do Mundo será diferente, pois o que o poeta leva para a cidade grande é justamente o que representa Itabira, ou seja, é como se em Alguma Poesia houvesse esse recalque seguido de um sentimento de culpa. De qualquer forma, o adulto reconhece como bonita uma história em que ele está afastado em decorrência da leitura, mas inserido na família por fazer parte daquele mundo (“menino entre mangueiras"). Mesmo sozinho, o menino faz parte da família. 


\section{Confidência do Itabirano}

Em Sentimento do Mundo, Drummond aborda pela primeira vez sua cidade natal como constituinte do eu poético. Ao mesmo tempo em que sua poesia de cunho social começa a ganhar força, Itabira passa a ser vista não mais como a cidade da vida besta, mas como um elemento de formação de sua personalidade lírica. Os elementos rurais e urbanos não são mais postos em oposição como acontecia, por exemplo, em "A rua diferente" (p.13), de Alguma Poesia.

Estamos diante de um momento em que ocorre tanto a intensificação da poesia participativa quanto a volta ao passado. Para Antonio Candido, essa polaridade é justamente o momento maduro da poesia de Drummond, pois temos "de um lado, a preocupação com os problemas sociais; de outro, com os problemas individuais, ambos referidos ao problema decisivo da expressão, que efetua sua síntese”. (CANDIDO, 2004: p. 68).

E é justamente nesses problemas individuais que "Confidência de Itabirano" parece situar-se. Conforme vimos argumentando, a herança deixada ao poeta em "Os bens e o sangue" está na raiz de alguns conflitos importantes da poética drummondiana. Dessa forma, o modo como o poeta se refere a sua cidade natal está também intrinsecamente relacionado com sua família. Vamos à leitura de "Confidência de Itabirano" (p.68):

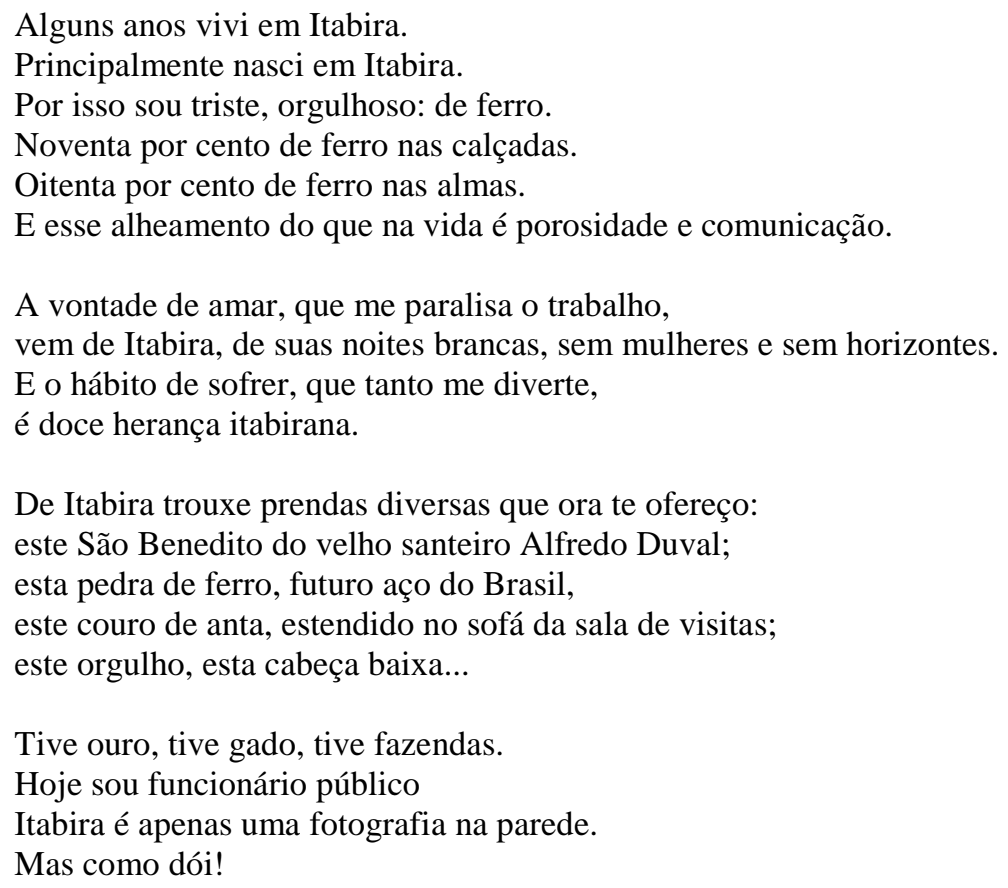


O primeiro aspecto a ser notado é como Itabira compõe a personalidade do eu lírico. Não apenas o fato de ter vivido na cidade é importante, mas principalmente de lá ter nascido. Antes mesmo de poder escolher o que deseja manter em si da cidade, o simples fato de nascer em Itabira já o define. Nesse caso, o itabirano não tem escolha. É como se a cidade legasse aos seus filhos uma de suas principais características: o ferro ("oitenta por cento de ferro nas almas"). Dessa forma, podemos pensar não apenas no caso do sujeito lírico, mas também em toda sua família como tendo as características do ferro: dureza, frieza, densidade. Essa questão é relevante porque, quando pensarmos na relação do poeta com o pai, muito desse ferro estará presente. A primeira estrofe nos apresenta ainda o "alheamento do que na vida é porosidade e comunicação". A porosidade aqui pode ser entendida como o que não é denso, é leve. E o alheamento à comunicação também marca a sua relação familiar, como veremos logo mais.

A “doce herança itabirana” chama a atenção na segunda estrofe. É sabido que a poesia de Drummond é marcada pelo sofrimento, ou pelo menos pelas inquietudes, que caracterizam o fazer poético sobre o que sente. Isso não significa, todavia, uma abordagem trivial, fácil. É um sentir marcado às vezes pela desconfiança, pela ironia, pela melancolia, isto é, mesmo que seja uma dor intensa, ela não é a exposição direta do eu lírico, há um tipo de mediação que revela apenas em parte esse sentimento. Como podemos notar no "Poema de sete faces", quando o poema cai em uma confissão a respeito de si ("mais vasto é meu coração"), a estrofe seguinte acaba por desfazer esse tom quase sentimentalista ("Eu não devia te dizer / mas essa lua / mas esse conhaque / botam a gente comovido como o diabo"). Esse "hábito de sofrer" que tanto o diverte é um dos elementos fundamentais para o seu fazer poético.

A estrofe seguinte situa o eu lírico no espaço. Sabemos que ele, distante de Itabira, trouxe consigo alguns objetos e muito de sua personalidade. Esses objetos (o São Benedito, a pedra de ferro, o couro de anta) representam o universo rural de onde provém. $O$ último elemento, colocado no sofá da sala de visitas, é nitidamente deslocado de seu contexto original. Mais do que os objetos, o eu lírico oferece também o orgulho e a cabeça baixa. São duas características que parecem se anular, de modo que a imagem do orgulhoso de cabeça baixa soe estranha. Mas essa é uma belíssima descrição do eu lírico criado por Drummond (que marcará também, em ambas as partes, sua relação com o pai).

A última estrofe indica a posição social específica de onde fala o sujeito lírico: a do funcionalismo público urbano. Funcionário que estava atrelado a um mundo rural de ouro, gado e fazendas, correspondente ao universo patriarcal de "Infância". Porém, Itabira é agora, 
dentro desse universo citadino, apenas uma fotografia na parede ${ }^{8}$. É no último verso que o poeta revela que Itabira ainda lhe é importante, mesmo que seja representada apenas pela foto. Ao dizer que Itabira dói, o eu lírico reconhece também uma dor maior, que diz respeito não apenas à cidade natal, mas também ao seu contexto, o que inclui o círculo familiar. A respeito disso, Gledson nos diz o seguinte:

\begin{abstract}
Mas aqui também à alienação, ou ao alheamento, contrapõe-se uma espécie de ligação, que faz com que o poema seja mais ambíguo do que parece à primeira vista. O ferro entra na alma, mas entra, ainda assim, e o hábito de sofrer, até a sua própria paralisia são coisas herdadas do passado, dos quais nem é capaz de se ressentir - "o hábito de sofrer, que tanto me diverte". Os vários objetos que conserva são sinais, embora fragmentários e pessoais, de o que o passado ainda está vivo. A reação final é agora simplesmente emocional - "Mas como dói!" O poeta é uma espécie de encruzilhada onde a herança do passado e as tensões do presente convergem sem, é claro, encontrar um equilíbrio. (GLEDSON, 1981: p.121)
\end{abstract}

Itabira sempre esteve presente na poesia de Drummond. Porém, é nesse momento que a abordagem deixa de ser ainda de quem tem restrições quanto ao seu passado. A cidade natal de Drummond é também o palco da tradição patriarcalista, que pode ser interpretada como oposição à chegada da modernidade, através das referências ao campo e do comportamento das pessoas; a partir de Sentimento do Mundo, quando a experiência urbana é mais intensa, esse ar interiorano deixa de ser estranho, ou pelo menos se ainda é estranho, agora faz parte da formação do sujeito lírico. Essa é uma diferença importante com relação a Alguma Poesia.

No caso de "Confidência de Itabirano", a lembrança de Itabira é representada, entre as outras prendas, pela fotografia na parede. Na poesia de Drummond, a fotografia e o retrato têm um papel importante por ativar a memória, mas também por tornar presente o passado do poeta. É o caso, por exemplo, de "Os mortos de sobrecasaca" (p.73) em que, apesar de sua destruição através da ação dos vermes, a fotografia transmite a vida dos mortos, ou seja, para muito além da imagem, sua presença está em quem ainda vive. "Retrato de família" (p.182) é também um poema importante na obra de Drummond. O retrato ganha vida e fita o poeta, que se contempla no retrato, formando uma espécie de imagem especular.

\title{
4. Em busca do tempo perdido
}

\footnotetext{
${ }^{8}$ Parece haver uma espécie de rebaixamento no fato de o eu lírico ter se tornado um funcionário público, como se estivesse rompendo a tradição familiar para se acomodar na burocracia. É um caso semelhante ao de Amanuense Belmiro, em que o funcionalismo público é como que uma derrota na vida: "Este velho que se assenta ao meu lado tem trinta anos de serviço, já recebe adicionais e ainda acredita que nasceu para o brilho e a dignidade da Igreja. [...] Acolá, outro velho, o Romualdo, que já requereu contagem de tempo para fins de aposentadoria, com todos os vencimentos, suspira, cada dia, à hora de encerrar-se o expediente: 'Eu dava para a política. Tinha jeito e tive padrinhos. Mas não tirei carta de bacharel, casei-me antes de tempo e aqui estou vegetando...' Há outros que teriam feito carreira no Exército, na alta administração, ou nas letras. Mas houve qualquer coisa que tudo atrapalhou, desviando-lhes a rota da vida." (ANJOS, Cyro Versiani dos. O amanuense Belmiro. São Paulo: Saraiva, 1949. p.36).
} 
De José, o poema "Viagem na família" (p.110) coloca pela primeira vez na obra de Drummond, explicitamente, a relação conflituosa do eu lírico com seu pai, antes uma lembrança dolorosa que propriamente um mero desentendimento familiar. É a partir daí que sua poesia, no que tange ao tema da família, ganha uma dimensão mais densa.

Não só a figura paterna é central para sua compreensão, mas também Itabira, de modo que poderíamos analisá-lo na seção anterior. De qualquer forma, isso só reforça a idéia de que a cidade natal e a família são temas inextricavelmente ligados. John Gledson notou que "Viagem na família" é um poema central na obra de Drummond:

\footnotetext{
"Viagem na família" é talvez a realização mais contundente de José. A tensão dramática sustentada, a intensidade com que o mundo morto torna à vida, a emoção sufocante, e o sentimento de carinho desperdiçado, todos dão a sensação que Drummond súbita e finalmente feriu uma corda que ao longo da luta dos livros anteriores the havia escapado. (GLEDSON, 1981: p.143)
}

As três primeiras estrofes do poema nos indicam onde se passa a tentativa de diálogo, o deserto de Itabira, que não é apenas o cenário para essa viagem, mas é vista como o palco no qual as ações do passado - trazidas à tona pela memória - ressurgem e provocam a tensão entre o poeta e o pai.

\author{
A rua que atravessava \\ a cavalo, de galope. \\ Seu relógio. Sua roupa. \\ Seus papéis de circunstância. \\ Suas histórias de amor. \\ Há um abrir de baús \\ e de lembranças violentas. \\ Porém nada dizia.
}

O último verso de todas as estrofes será a marca do silêncio do pai, "porém nada dizia", o que cria, pela repetição, uma angústia, resolvida apenas no final do poema. A figura paterna surge como uma sombra, que toma o poeta pela mão, conduzindo-o ao interior da família, como Virgílio levando Dante para adentrar o inferno. É uma espécie de viagem a Itabira em busca do tempo perdido, o tempo da convivência, mesmo tensa, entre pai e filho:

\title{
No deserto de Itabira a sombra de meu pai tomou-me pela mão. \\ Tanto tempo perdido.
}

A partir da quinta estrofe, o eu lírico abandona a descrição da cidade e passa para a viagem. Nessa estrofe, há a imagem das escravas (ou pelo menos das negras que, mesmo no 
período posterior à escravidão, eram tratadas como tal) relacionadas ao sexo, já retratadas em "Edifício Esplendor" (p.96) e "Iniciação amorosa" (p.29):

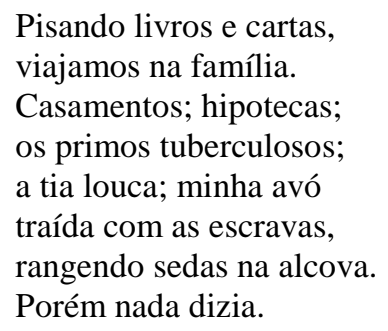

A relação entre sua família e a escravidão é importante na obra de Drummond na medida em que revela o comportamento daquela, afetando diretamente eu lírico. Ou seja, a "preta velha" que preparava o café, a lavadeira que o iniciou no amor, as trinta crioulas na casa paterna e essas escravas que traíram sua avó funcionam na obra de Drummond como uma representação do patriarcalismo ainda existente, porém nitidamente em decadência. É curioso também que, pelo menos até Claro Enigma, não aparecem escravos homens. O fato de o poeta falar sobre o sexo entre escravas (ou mulheres oriundas da escravidão) e os homens de sua família está diretamente relacionado com o comportamento masculino dessa família, ou num plano mais amplo, da família patriarcal brasileira.

Da sexta estrofe em diante o poema se volta para o conflito entre a sombra do pai e o poeta, que se torna mais intenso, passando quase à exasperação:

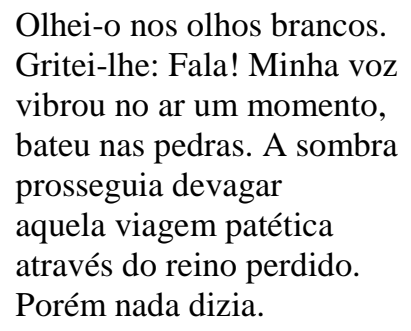

A falta de palavras, que confirmam o gesto do pai, parece condenar o eu poético. A busca do diálogo, que o leva ao grito e à repetição exaustiva, é também a necessidade do reconhecimento paterno de sua condenação. A figura paterna na obra de Drummond ganha maior dimensão a partir deste momento, ressaltando seu lado melancólico.

Tomamos por referência o conceito de melancolia elaborado por Sigmund Freud (1992) em "Luto e Melancolia", no qual a melancolia é entendida como um estado de espírito semelhante ao do luto. A grande diferença é que este é um estado passageiro, enquanto aquela não. Outra diferença importante é o fato de que no luto o sujeito sabe qual é o objeto da perda e em pouco tempo a supera, ao passo que na situação melancólica nem sempre o objeto da 
perda é conhecido e, caso seja, não se sabe ao certo qual era a sua significação. Dentre outras características do estado de melancolia, podemos destacar "o desânimo profundamente doloroso, uma suspensão do interesse pelo mundo externo" e, principalmente, "rebaixamento do sentimento de auto-estima" (FREUD, 1992, p.131).

Assim, pode-se dizer que "Viagem na família" é um poema cujo traço melancólico revela uma face significativa da obra de Drummond ${ }^{9}$. Essa melancolia é ativada pela memória, ou seja, a tentativa do diálogo com o familiar morto é a busca pela reconciliação do eu lírico com a lembrança do pai, que é veementemente negada até a última estrofe do poema. Durante a viagem a sombra do pai se nega a falar, prosseguindo sempre na "viagem patética ao reino perdido". Esse também é o reino da família.

É importante notar, ainda, o recurso estilístico usado para manter a tensão do momento. Como as estrofes terminam com o verso "porém nada dizia", nesta última estrofe mencionada esse verso é modificado para evitar a rima "desprendia" e "dizia", fazendo com que a dissonância seja mantida tanto na forma quanto no conteúdo do que está sendo dito.

$\mathrm{Na}$ estrofe seguinte, fica claro que o silêncio paterno representa também algo maior, talvez o silêncio familiar.

$$
\begin{aligned}
& \text { E eram distintos silêncios } \\
& \text { que se entranhavam no seu. } \\
& \text { Era meu avô já surdo } \\
& \text { querendo escutar as aves } \\
& \text { pintadas no céu da igreja; } \\
& \text { a minha falta de amigos; } \\
& \text { a sua falta de beijos; } \\
& \text { eram nossas difíceis vidas } \\
& \text { e uma grande separação } \\
& \text { na pequena área do quarto }
\end{aligned}
$$

A dificuldade de relacionamento se estende às relações familiares como um todo. Mas nesse caso, a separação não é física, como era em "Infância", pois mesmo na "pequena área do quarto" a distância permanece.

As duas últimas estrofes são como que a revelação do amor existente entre o poeta e a família e também do fato de ser este amor reconhecido apenas postumamente.

$$
\begin{aligned}
& \text { A pequena área da vida } \\
& \text { me aperta contra seu vulto, } \\
& \text { e nesse abraço diáfano } \\
& \text { é como se eu me queimasse } \\
& \text { todo, de pungente amor. } \\
& \text { Só hoje nos conhecermos! }
\end{aligned}
$$

\footnotetext{
${ }^{9}$ Para outra abordagem sobre a melancolia em Drummond, cf. CAMILO (2001). Lá é feita uma abordagem da melancolia pelo viés da perda da ilusão da mudança social de Rosa do Povo em Claro Enigma.
} 


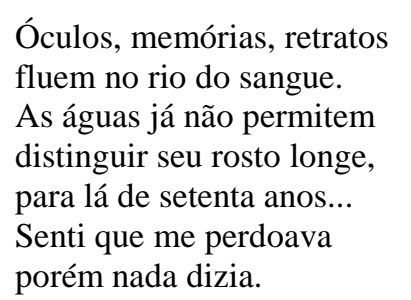

As águas cobrem o bigode, a família, Itabira, tudo.

Aqui, aparece a imagem do rio de sangue, que também será retomada em "Como um presente" (p.186), de A Rosa do Povo, em "Convívio" (p.287) e em "Os Bens e o sangue" (p.282), de Claro Enigma. Talvez esta seja a imagem que melhor represente sua relação com a família, pois ao mesmo tempo em que dá a sensação de fluxo permanente, de continuidade, é também marcada pela dor. Aliás, é nesse rio que fluem "óculos, memórias, retratos". De certa forma, esse rio de sangue flui também através do retrato, como em "Retrato de família", de A Rosa do Povo.

No fim do poema, o perdão do pai é sentido pelo eu poético, mas essa é uma reconciliação que continua sem resposta. Perdão do quê? Este parece ser mais um traço melancólico presente no poema. O sentimento de baixa auto-estima é uma marca da poesia sobre a família em Drummond. O maior exemplo é sua própria gaucherie. O pedido de perdão talvez seja pelo pouco convívio, pela distância na pequena área da vida. É o filho quem assume a culpa, mesmo sendo a dificuldade de relação tanto sua como do pai. A última estrofe, segundo John Gledson (1981, p.150), dilui a tensão do poema, "como índice da inutilidade da luta que o poema dramatiza. Nada pode reparar a divisão ou derrotar a morte". No último verso, Itabira está no mesmo plano da família. Para o sujeito lírico, ambas representam tudo.

\section{0 adubo da poesia}

O poema "Os bens e o sangue" (p.282), do qual partimos e ao qual chegamos, nos oferece uma chave de leitura para a temática da família na poesia de Carlos Drummond de Andrade. Integrando a seção "Selo de Minas", é o poema que dá voz à família para manifestar seu legado a esse eu lírico que perseguimos até aqui. Ou seja, até este momento, a relação familiar fora vista pela perspectiva do gauche, da tortuosidade que o caracteriza. Quando o olhar familiar passa a incidir sobre ele, podemos compreender o quanto a sua trajetória poética era um desígnio dos ancestrais.

Como nota Vagner Camilo, este é um poema 
que, pelo tema, ajustar-se-ia melhor ao caderno "Os lábios cerrados", dedicado à família, mas foi incluído em "Selo de Minas", que trata da terra natal, talvez porque Drummond visasse, com isso, frisar o modo como a história familiar não pode ser pensada independentemente da história da província. (CAMILO, 2001, p.165)

O poema "estabelece a ligação entre o passado da família e o presente do indivíduo, através da forma altamente significativa de um testamento" (CANDIDO, 2004, p.85). Assim sendo, ele não só determina o modo como o sujeito lírico concebe as relações familiares, mas também ressignifica traços poéticos importantes de Drummond.

A venda dos bens da família na primeira parte é motivada pelos descendentes que virão - dentre os quais o poeta - que será o principal representante da decadência do universo patriarcal de Minas:

Mas fique esclarecido:

somos levados menos por gosto do sempre negócio $q$ no sentido

de nossa remota descendência ainda mal debuxada no longe dos serros.

Ao vender seus bens, a família deserda o poeta a fim de fazer com que este ("filhos netos bisnetos tataranetos") se desapegue da fortuna e não se iluda na vida ("e que nada, porém nada / o há de ter desenganado):

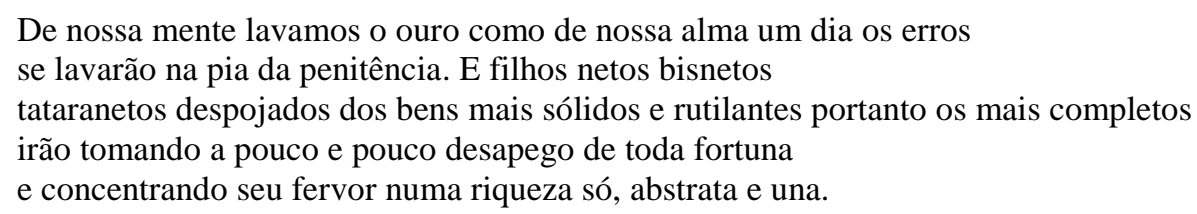

Nesse momento, começamos a perceber a circularidade da poesia sobre a família em Drummond, pois se até Claro Enigma é eu lírico quem a busca, agora, na voz de seus ancestrais, percebe-se sua preocupação com o futuro da prole. A venda dos bens materiais é o início da trajetória do gauche, antes mesmo de ele ter nascido.

Assim, se levarmos em conta que este poema estabelece um destino a ser seguido pelo eu lírico, um caminho do qual é impossível desviar, isso deve estar presente também em sua obra anterior. Ou seja, características importantes da poética drummondiana como a busca do diálogo com o pai, "a idéia da família viajando através da carne", a relação com sua cidade natal e a própria gaucherie, se assim for, deverão ser determinadas por uma herança familiar. Pois é justamente este o caminho da poesia de Drummond, que parece culminar, pelo menos no que diz respeito a essa inquietude, em Claro Enigma. O caminho da afirmação poética da herança familiar está completamente expresso apenas em “Os Bens e o Sangue”. Apenas nesta obra o poeta encontra as raízes do conflito pelo qual passa boa parte de sua obra anterior, fechando, assim, esse círculo poético. 
Na terceira parte, tanto a negação da família - percebida no conflito com a figura paterna, que depois acaba em resignação, ou ainda no fato de ser o poeta a "vergonha da família" - quanto sua procura fazem parte do destino que o sujeito lírico inevitavelmente deve seguir. O caminho que Drummond percorre em sua obra é justamente esse, já que com o passar do tempo, pelo menos nas obras aqui consideradas, essa temática ganha mais espaço quanto maior é sua problematização.

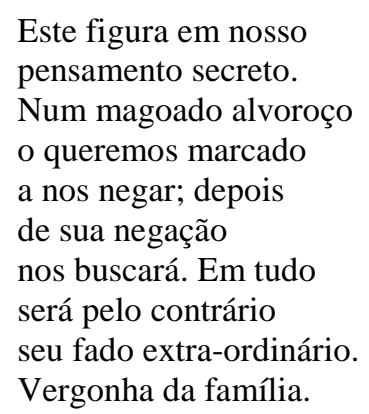

Neste trecho fica claro que apenas em "Os bens e o sangue" Drummond encontra uma origem para os conflitos familiares. Deixa de ser o anjo torto, ou um possível conflito, ou qualquer questão psicologizante. Essa origem arraigada na família situa historicamente o conflito da gaucherie, marcado também pelos do patriarcalismo brasileiro.

Depois de deserdar o poeta dos bens materiais e de lhe deixar como herança a riqueza "abstrata e una", a voz da família irá traçar seu caminho:

IV

Este hemos por bem

reduzir à simples

condição de ninguém.

Não lavrará campo.

Tirará sustento

de algum mel nojento.

Há de ser violento

sem ter movimento.

[...].

Este será tonto

e amara no vinho

um novo equilíbrio

e seu passo tíbio

sairá na cola

de nenhum caminho.

A família reduz o herdeiro à "condição de ninguém" a fim de lhe fazer o bem. Assim, a atitude dos ancestrais não é de quem roga uma praga, é antes uma atitude benéfica ao descendente ("a praga que te rogo para teu bem será"). Já vimos em versos anteriores que a família vende os bens para que o poeta busque outra riqueza. Agora, é determinado também o comportamento do familiar que está por vir, "há de ser violento sem ter movimento". É a 
predestinação do gauche pela voz da família. A gaucherie drummondiana deixa, explicitamente, de ser atribuída apenas ao anjo torto. Aquela fuga de "Poema de sete faces" para o sobrenatural encontra agora uma origem histórica: os ascendentes do poeta, exproprietários de fazendas, que vendem o que têm e lhe determinam o caminho a ser seguido. Uma imagem fundamental é a daquele que "será tonto e amará no vinho um novo equilíbrio", isto é, um equilíbrio ébrio, inconstante.

Depois de terem anunciado sua gaucherie, na última parte do poema os ancestrais anunciam que o poeta, através de sua poesia, servirá à família. Esta é como que uma síntese de seu destino no círculo familiar. Há o reconhecimento da incapacidade para a lida do campo (ou seja, o anúncio do "fazendeiro do ar"), o reconhecimento de sua poesia e da família sendo um dos substratos de sua obra.

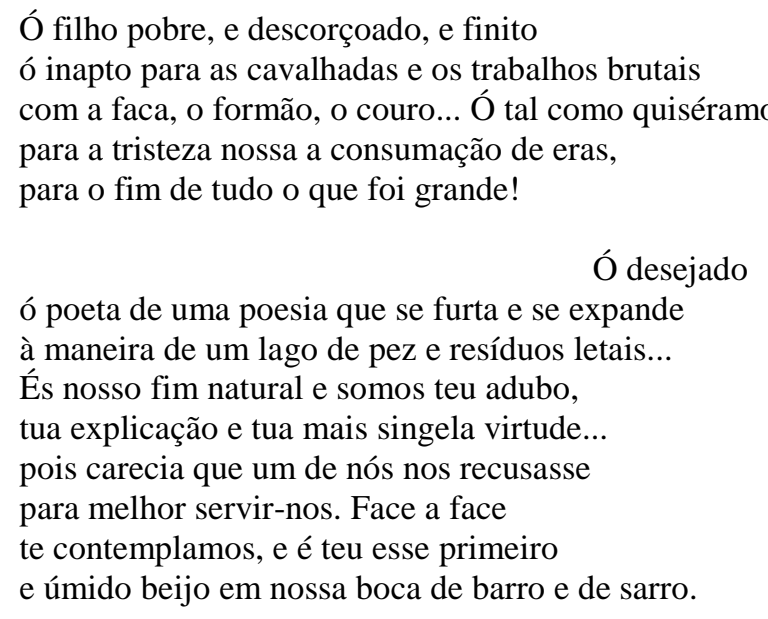

Fim natural, adubo, explicação e singela virtude é o que define o poeta segundo os ancestrais. Vale notar o movimento circular da poesia sobre a família em Drummond mencionado acima, porque na medida em que o poeta encerra uma trajetória, a familiar, inicia outra, a da poesia. Assim, o fim natural no plano histórico, é seu adubo poético. Camilo observa que

\footnotetext{
Na medida em que tudo foi tal como quiseram os antepassados; em que a recusa acabou sendo um modo de melhor servi-los, desmerece e anula-se por completo toda e qualquer tentativa de afirmação de independência, de autonomia e de poder de decisão do fazendeiro do ar em relação ao clã e seus valores, mesmo quando se acreditava o mais afastado deles, ao conceber a utopia de uma nova ordem social que era justamente a oposição e a negação da encarnada por eles. (CAMILO, 2001: p.273)
}

Da mesma forma, é a família quem explica a poesia, assim como quem caracteriza sua virtude. Em "Os bens e o sangue", ao dar voz à família, Drummond consegue determinar o movimento poético de sua obra e a importância que tanto Itabira quanto a família têm. Mesmo que quisesse, seria impossível fugir desse tema, já que mesmo sua negação é, no final das contas, o cumprimento do destino familiar. 


\title{
6 Considerações finais
}

Argumentamos até aqui que é em Claro Enigma que a relação entre eu lírico e família é mais tensa, que é onde os ancestrais do poeta ganham voz e deixam claro o seu legado. Partindo deste volume de poesias, propusemos a linha de interpretação aqui desenvolvida, ou seja, o que é deixado de herança ao poeta é o que determina como ele trata o tema da família representada principalmente pela figura paterna -, da cidade natal, de sua própria gaucherie.

De certa forma, essa é uma leitura que pelo menos Antonio Candido e Vagner Camilo já haviam mencionado, porém acabaram por não desenvolvê-la. Candido diz a respeito de "Viagem na família":

\begin{abstract}
Este poema abre um ciclo anunciado por alguns poemas anteriores e desenvolvidos paralelamente à poesia social, prolongando-se todavia depois dela, num ritmo de obsessão crescente. E é sem dúvida curioso que o maior poeta social de nossa literatura contemporânea seja, ao mesmo tempo, o grande cantor da família como grupo e tradição. Isto nos leva a pensar que talvez este ciclo represente na sua obra um encontro entre as duas inquietudes, a pessoal e a social, pois a família pode ser explicação do indivíduo por alguma coisa que o supera e contém. (CANDIDO, 2004: p.83) (grifo nosso)
\end{abstract}

Fica claro que Candido coloca a relação entre poesia sobre a família e o destino que lhe é incumbido, advindo também da decadência do patriarcalismo mineiro.

Vagner Camilo (2001) quando trata da culpa atribuída ao fato de o poeta ser um fazendeiro do ar, diz: "já não se trata mais, portanto, de uma decisão a ser tomada, mas das conseqüências de uma decisão que ocorreu no tempo e retratada em fase anterior da obra" (p.266). Dessa forma, ele tem consciência de que a poesia sobre a família em Drummond percorre um trajeto ao longo de sua obra e que tem em Claro Enigma um momento decisivo.

"Os bens e o sangue" é o primeiro poema da obra de Drummond no qual é apresentado o ponto de vista da família. Até esse momento ele varia bastante: em "Infância", de Alguma Poesia, parece haver uma espécie de recalque quanto ao fato de o eu lírico estar relacionado com o universo rural, provinciano, mas ao mesmo tempo, o reconhecimento de que há um conflito sob aquela tranqüilidade; em "Viagem na família", de José, e "Como um presente", de Rosa do Povo, o conflito é explícito, e a figura do pai representa também a tensão familiar.

O recurso do retrato contribui para a melhor expressão desse conflito. É sua utilização que melhor coloca a relação entre a família e Itabira. Estes são dois temas indissociáveis pelas lembranças que o retrato suscita. Lembranças essas que muitas vezes referem-se ao mundo rural e patriarcal de Itabira, como em "Edifício Esplendor", em que o contraste entre a cidade e o campo é fundamental para o poema. Quando o retrato faz referência à família, como em 
"Os mortos de sobrecasaca" ou em "Retrato de família", é trazido à tona o fato de os familiares ainda estarem presentes (“a idéia de família viajando através da carne”) em quem vive, em quem olha o retrato, o que implica angústia, inquietude. Há em Drummond uma incapacidade de fugir do destino. Mesmo quando procura negar a família, quando questiona a autoridade paterna, está cumprindo o que vaticinaram os ancestrais em "Os bens e o sangue".

Outra questão de que tratamos é como a configuração da tortuosidade, da gaucherie, tem origem na herança familiar. Em "Poema de sete faces", a explicação para o fato de ser gauche foge à lógica racional, ou seja, nesse primeiro momento da poesia de Drummond o que determina a torção é algo que ultrapassa a história. Explicação completamente diferente da que encontraremos em "Os bens e o sangue", em que a decadência do mundo patriarcal mineiro está diretamente relacionada com o destino a ser seguido pelo eu lírico. Dessa forma, temos a passagem do sentimento individual como explicação da gaucherie (e, conseqüentemente, da poesia) para a condição social e histórica do universo patriarcal brasileiro. Em Claro Enigma há um fechamento de um ciclo (e a abertura de outro) na poesia de Drummond, o ciclo de formalização das origens do tema da família, que vai do anjo torto à herança familiar.

\section{Referências}

ANDRADE, Carlos Drummond de. Poesia Completa. Rio de Janeiro: Nova Aguilar, 2003.

ANJOS, Cyro Versiani dos. O amanuense Belmiro. São Paulo: Saraiva, 1949.

ARRIGUCCI JR, Davi. Coração partido: uma análise da poesia reflexiva de Drummond. São Paulo: Cosac Naify, 2002.

CAMILO,Vagner. Drummond: da Rosa do Povo à Rosa das Trevas. São Paulo: Ateliê Editorial, 2001.

CANDIDO, Antonio. "Inquietudes na poesia de Drummond". In: Vários Escritos. Rio de Janeiro: Ouro sobre Azul; São Paulo: Duas Cidades, 2004.

"Poesia e ficção na autobiografia". In: A educação pela noite. Rio de Janeiro: Ouro sobre Azul, 2006.

FREUD, Sigmund. "Luto e Melancolia". Trad. Marilene Carone In: Novos estudos CEBRAP, São Paulo, no 32, p. 130-142, março 1992.

GLEDSON, John. Poesia e poética de Carlos Drummond de Andrade. São Paulo: Duas Cidades, 1981. 
MORAES NETO, Geneton. Dossiê Drummond. São Paulo: Globo, 2007.

SANT'ANNA, Afonso Romano de. Drummond, o "gauche” no tempo. Rio de Janeiro: Lia, INL, 1972.

WATT, Ian. Mitos do individualismo moderno: Fausto, Dom Quixote, Dom Juan, Robinson Crusoe. Trad. Mario Pontes. Rio de Janeiro: Jorge Zahar, 1997. 